\title{
MirosŁaW SAdOWSKI
}

Uniwersytet Wrocławski

\section{NATURALNE I SPOŁECZNE PRAWA CZŁOWIEKA W NAUCZANIU PAPIEŻA LEONA XIII}

Uczestnicy współczesnego dyskursu politycznego w poszukiwaniu aksjologicznych podstaw dla ustawodawstwa krajowego czy międzynarodowego odwołują się do takich pojęć, jak: godność osoby ludzkiej, dobro wspólne ${ }^{1}$, wolność, równość, sprawiedliwość ${ }^{2}$. Do tych fundamentalnych kategorii zaliczyć należy również ideę praw człowieka ${ }^{3}$.

${ }^{1}$ Szerzej na ten temat por. M. SADOwSKI, Godność człowieka - aksjologiczna podstawa państwa i prawa, [w:] Studia Erasmiana Wratislaviensia - Wrocławskie Studia Erazmiańskie, Zeszyt Naukowy Studentów, Doktorantów i Pracowników Uniwersytetu Wrocławskiego, Wrocław 2007, s. 8-28, oraz Tenże, Godność człowieka $i$ dobro wspólne jako fundament wartości europejskich. Propozycje katolickiej nauki społecznej, [w:] Aksjologiczne i praktyczne aspekty integracji europejskiej, pod red. E. Kozerskiej i T. Schefflera, Wrocław 2007, s. 99-110, a nadto Tenże, Godność człowieka i dobro wspólne w papieskim nauczaniu społecznym (1878-2005), Wrocław 2010, passim. H. IzDEBSKI, Fundamenty wspótczesnych państw, Warszawa 2007, passim, nie zawahał się zaliczyć idei ludzkiej godności i dobra wspólnego do fundamentów konstytuujących współczesne państwa.

${ }^{2}$ Por. interesująco w kwestii sprawiedliwościA. MacIntyre, Czyja sprawiedliwość? Jaka racjonalność?, Warszawa 2007, passim.

${ }^{3}$ W XXI wieku funkcjonuje wiele koncepcji praw człowieka, a za najbardziej istotne ich cechy przyjmuje się ich przyrodzony charakter, niezbywalność i fakt, że wypływają z prawa ponadpozytywnego. Z tych powodów, ważność praw człowieka nie zależy od ich uznania ze strony porządku państwowego. Współcześnie uchodzą one nawet za podstawę stosunków międzynarodowych, por. M. MACIEJEWSKI, Uźródeł 
Należy podzielić pogląd głoszący, że prawie wszystkie współczesne ideologie polityczne i oparte na nich systemy ustrojowo-prawne odwołują się do idei praw człowieka. Prawa te wchodzą w skład doktryn socjalistycznych, liberalnych, jak i niewiele mającego z nimi wspólnego nauczania społecznego Kościoła katolickiego ${ }^{4}$. Wydaje się poza dyskusja, że w katolickiej nauce społecznej kwestia praw człowieka pojawiła się dopiero za pontyfikatu Leona XIII ${ }^{5}$, jakkolwiek traktat hiszpańskiego dominikanina Bartolomé de Las Casas z 1552 r. można uznać za ważny dokument poprzedzający późniejsze deklaracje praw człowieka ${ }^{6}$.

Wybrany 20 lutego 1878 r. na papieża arcybiskup Perugii, kardynał Vincenzo Joacchimo Aloiso Pecci (1810-1903) przybrał imię Leona XIII. Należy podkreślić jego doniosły wkład w rozwój katolickiej nauki społecznej, papież ten jest bowiem słusznie uznawany za twórcę papieskiej nauki społecznej ${ }^{7}$, a ogłoszona przez niego 15 maja $1891 \mathrm{r}$. encyklika Rerum novarum (encyklika o kwestii robotniczej) stała się trwałym fundamentem katolickiej nauki społecznej ${ }^{8}$. W mojej ocenie

liberalnej koncepcji praw człowieka i obywatela, «Przegląd Prawa i Administracji» 63/2004, s. 7.

4 Tamże, s. 8.

5 Tak też F. J. Mazurek, Prawa człowieka w nauczaniu społecznym Kościoła (od papieża Leona XIII do papieża Jana Pawła II), Lublin 1991, s. 33. Autor ten uważa, błędnie moim zdaniem, że problematyka praw człowieka była już wcześniej znana Kościołowi.

${ }^{6}$ B. De Las Casas, Krótka relacja o wyniszczeniu Indian, Poznań 1988, passim. Marek Maciejewski zalążków idei praw człowieka dopatruje się w poglądach myślicieli starożytnych, przyjmując, że ich rozważania o prawie naturalnym, przyczyniły się do ukształtowania w późniejszych wiekach, liberalnej koncepcji praw człowieka, TENŻE, Uźródet liberalnej koncepcji praw człowieka..., s. 8.

7 Por. M. Sadowski, Państwo $w$ doktrynie papieża Leona XIII, b.m.w. 2002, passim.

8 J.-Y. CALvez, Encyklika 'Rerum novarum' a współczesne problemy społeczne, «Przegląd Powszechny» 5(837)/1991, s. 239. Godzi się w tym miejscu zauważyć, że od czasu ogłoszenia przez papieża Piusa XI encykliki Quadragesimo anno z 15 maja 1931 r., także późniejsi papieże odwoływali się wprost do encykliki Rerum novarum (encyklika Mater et magistra wydana przez Jana XXIII z 15 maja 1961 r., zatem 
jego pontyfikat miał przełomowe znaczenie zarówno dla katolickiej nauki społecznej, jak i dla nauczania Kościoła o prawach człowieka9.

Leon XIII podczas swojego długiego urzędowania na Stolicy Apostolskiej ogłosił szereg dokumentów, w których pojawiają się wątki społeczne ${ }^{10}$, a papieskie wypowiedzi dotyczące człowieka $\mathrm{i}$ jego praw były liczne i różnorodne ${ }^{11}$. Jak w pełni zasadnie wskazał Bogusław

w 70. rocznicę Rerum novarum, a nadto dwie encykliki Jana Pawła II Laborem exercens z 14 września 1981 r., wydana w 90. rocznicę Rerum novarum, i Centesimus Annus z 1 maja 1991 r., a więc ogłoszona w 100. rocznicę Rerum novarum). Jan Paweł II stwierdził wprost, iż data ogłoszenia encykliki Rerum novarum ,poczynając od czterdziestej aż po dziewięćdziesiątą rocznicę, była zaszczytnie wyróżniania przez uroczyste dokumenty Papieży. Rzec zatem można, jej historyczną drogę wyznaczały systematycznie ogłoszone inne pisma, które przypominały ja, a jednocześnie aktualizowały". Por. Jan Paweł II, Centesimus Annus, Wrocław 1991, s. 5.

9 Szerzej na ten temat por. M. SAdowski, Państwo w doktrynie papieża Leona XIII..., s. $185 \mathrm{i} \mathrm{n.}$

${ }^{10}$ W swoich enuncjacjachLeon XIII zajmował się: stosunkiem Kościoła do socjalizmu, naturą i pochodzeniem władzy państwowej, katolickim rozumieniem wolności, kwestią robotniczą, własnością, problematyką demokracji, stosunkami państwo-Kościół, edukacją, patriotyzmem czy chrześcijańskim rozumieniem małżeństwa.

11 Problematyka praw człowieka pojawia się w następujących encyklikach: Encyklika 'Quod Apostolici muneris' z 28 grudnia 1878 r. o sekcie socjalistów, komunistów i nihilistów, Warszawa 2002; Encyklika 'Arcanum divinae sapientiae' z 10 lutego 1880 r. o sakramencie matżeństwa, Warszawa 2002. Papież użył tutaj określenia ,prawa człowieka do zbawienia, s. 7. Encyklika 'Diuturnum illud' z 29 czerwca 1881 r. o pochodzeniu władzy państwowej, http://www.nonpossumus.pl/ encykliki/Leon_XIII/diuturnum_illud/di.php. Encyklika In plurimis z 5 maja 1888 r. oniewolnictwie,por.http://www.vatican.va/holy_father/leo_xiii/encyclicals/documents/ hf_lxiii_enc_05051888_inplurimis_en.html; Encyklika 'Libertas praestantissimum' z 20 czerwca 1888 r. o wolności, [w:] 'Lumen de Caelo'. Erweiterte Ausgabe des „Leo XIII. der Lehrer der Welt”. Praktische Ausgabe der wichtigsten Rundschreiben Leo XIII. und Pius XI. In deutscher Sprache mit Ubersicht und Sachregister, hrsg. von C. Ulitzka, Papstlicher Hauspraelat, Ratibor 1931. Encyklika 'Sapientiae christianae' z 10 stycznia 1890 r. o obowiqzkach chrześcijanina jako obywatela państwa, b.r. i m.w., sygn. 99397, a zwłaszcza 'Rerum novarum', Jego Świqtobliwości Leona, z opatrzności Bożej papieża XIII, encyklika o robotnikach z 15 maja 1891 r. Osobne odbicie z „Notyfikacyj” Kuryi Książęco-Biskupiej w Krakowie, Nr VII i VIII z r. 1891, Kraków 1891. 
Banaszak papież ten odrzucił zachowawcze podejście poprzedników w kwestii praw jednostki i w encyklice Rerum novarum przedstawił wiele nowatorskich koncepcji ${ }^{12}$. Należy dopowiedzieć, że nauczanie Leona XIII przypada na przełom XIX i XX wieku, zatem papież w swoich rozważaniach nie dokonał dystynkcji praw człowieka na prawa podstawowe ${ }^{13}$, ani też nie mógł przyporządkować ich do jednej $\mathrm{z}$ generacji praw człowieka ${ }^{14}$, były to bowiem koncepty znacznie późniejsze. W poglądach Leona XIII wyróżnić możemy: naturalne i społeczne prawa człowieka ${ }^{15}$.

Już na wstępie warto zrekonstruować papieskie rozumienie prawa, pozwoli to bowiem lepiej uwypuklić jego koncepcję praw człowieka. Istotną enuncjacją papieska, która poruszała analizowaną problematykę była encyklika Sapientiae christianae - o obowiązkach chrze-

12 B. BanaszaK, Prawo konstytucyjne, Warszawa 1999, s. 377. W moim przekonaniu również $\mathrm{w}$ innych enuncjacjach tego papieża pojawiają się kwestie dotyczące praw człowieka.

13 Termin ,prawa podstawowe” pochodzi z prawa europejskiego. Z etymologii słowa „podstawowe” można wywnioskować, że prawa te stoją w hierarchii praw człowieka najwyżej i stanowią podstawę dla innych praw człowieka, wynikają wprost z moralności oraz znajdują w niej bezpośrednie oparcie, S. HAMBURA, M. MuszYŃsKi, Karta Praw Podstawowych z komentarzem, Bielsko-Biała 2001, s. 209.

${ }^{14}$ Odnośnie typów praw człowieka, ich katalogu, czy generacji por. M. PIECHOwIAK, Filozofia praw człowieka. Prawa człowieka w świetle ich międzynarodowej ochrony, Lublin 1999, s. 65-76. Jak wskazał M. Piechowiak współcześnie przyjmuje się typologię, która została przedstawiona przez Karla Vasaka. Autor ten zaproponował podział praw człowieka na trzy kategorie, które odpowiadają układowi treści Powszechnej Deklaracji Praw Człowieka: 1) prawa osobiste i polityczne; 2) prawa gospodarcze, socjalne i kulturalne; oraz 3) prawa solidarnościowe, Tamże, s. 65. Z kolei R. ANDRZEJCZuK, Prawa człowieka podstawa prawa narodów do samostanowienia, Lublin 2004, s. 115150, analizując generacje praw człowieka wskazuje na zasady, które je poprzedzają, pisze bowiem: 1) zasada wolności i prawa wolnościowe jako pierwsza generacja praw człowieka; 2) zasada równości i prawa społeczne jako druga generacja praw człowieka; 3) zasady solidarności i pomocniczości oraz prawa solidarnościowe jako trzecia generacja praw człowieka.

15 Por. w tym duchu H. Skorowski, Problematyka praw czlowieka ${ }^{3}$, Warszawa 2005, s. 38, a także F. J. MAZUReK, op. cit., s. 33. 
ścijan jako obywateli państwa ${ }^{16}$ z 1890 r. W dokumencie tym papież przedstawił definicję prawa posiłkując się kategorią dobra wspólnego. „Prawo - pouczył - nie jest czym innym, jak rozporządzeniem wydanym przez prawowitą władzę odpowiednio do zasad rozsądku, a ku ogólnemu dobru"17. Tym samym Leon XIII wywodził, że stanowienie praw powinno nie tylko odpowiadać zdrowemu rozsądkowi, ale również służyć bonum commune. Zdaniem autora encykliki prawowita jest jedynie ta władza, która pochodzi od Boga ${ }^{18}$, i dlatego chrześcijanie będą jej posłuszni, ponieważ posiada ona pewien odblask potęgi i majestatu Bożego. Nie do przyjęcia jest, zdaniem papieża, taki rozsądek (rozum), który sprzeciwia się prawdzie i rozumowi boskiemu, za prawdziwe zaś można uznać tylko te dobra, które są zgodne z najwyższym i niezmiennym dobrem ${ }^{19}$. Państwo powinno stanowić sprawiedliwe prawa, które będą sprzyjać powiększaniu dobra wspólnego. Zadaniem bowiem prawa, jest zabezpieczenie realizacji celów i zadań państwa. Ponieważ funkcją prawa stanowionego przez państwo (prawowitą władzę) jest kierowanie życiem człowieka, tak aby umożliwić mu osiaganie dobra, a unikanie zła, dlatego prawo ma charakter moral-

${ }^{16}$ Encyklika papieża Leona XIII 'Sapientiae Christianae' - o obowiazkach chrześcijanina jako obywatela państwa, z 10 stycznia 1890 r., b.r. i m.w., sygn. 99397.

17 Tamże, s. 6. Identyczną definicję sformułował w encyklice Au millieu des sollicitudes, gdzie napisał: „Prawo jest przepisem wydanym w myśl rozumu i dla dobra zbiorowości, ogłoszonym przez tych, co w tym celu dzierżą mandat władzy”, Encyklika Au millieu des sollicitudes z 16 lutego 1892 r. o Kościele i państwie we Francji, por. http://www.papalencyclicals.net/Leo13/113cst.html. Definicja przedstawiona przez Leona XIII została zapożyczona z koncepcji św. Tomasza z Akwinu.

18 Zadaniem papieża „Tylko ta władza jest prawowita, która pochodzi od Boga, pierwszego i najwyższego władcy, który sam jeden może nadać człowiekowi władzę nad człowiekiem... nie ma... mowy o zasadach, dyktowanych przez rozsądek, gdzie zdeptana jest prawda i prawo Boże. Wreszcie nikomu na pożytek wyjść nie może to, co sprzeciwia się najwyższemu, a niezmiennemu dobru, co oddala ludzi od miłości Boga", Sapientiae Christianae, s. 6.

19 Sapientiae Christianae, s. 7, por. też K. Grzybowski, B. SobolewsKa, Doktryna polityczna i społeczna papiestwa (1789-1968), Warszawa 1971, s. 59, a nadto J. F. Godlewski, Katolicka myśl kościelna o prawie i państwie, Warszawa 1985, s 161. 
ny, to znaczy musi być zgodne $\mathrm{z}$ prawem naturalnym ${ }^{20}$. Normy prawa stanowionego powinny wskazywać chrześcijaninowi co powinien czynić, a czego unikać. Normy ustanowione ,,bez upoważnienia Bożego i przeciw woli Bożej nie są ani prawem ani ustawa" 21 . Aby prawo pozytywne było sprawiedliwe, musi być zgodne z prawem naturalnym ${ }^{22}$.

O prawie naturalnym nauczał także we wspomnianej już encyklice Libertas prsestantissimum wskazując, że ,jest ono zapisane i osadzone w duszy każdego poszczególnego człowieka; ono jest samo w sobie ludzkim rozumem, który nakazuje dobro, a zabrania zła"23. W analizowanej enuncjacji dopowiedział, że celem prawa jest ochrona ludzkiej wolności, wskazuje ono bowiem człowiekowi co powinien czynić, a czego unikać ${ }^{24}$. Prawo jest niezbędne rozumnemu człowiekowi, al-

${ }^{20}$ Papież napisał: „Gdy prawa państwa zbaczają od prawa Bożego, gdy sprzeciwiają się prawom religii chrześcijańskiej i Kościoła ... wtenczas zdrożnem jest ich słuchać, obowiązkiem zaś opierać im się", Sapientiae Christianae, s. 6-7.

21 Tamże, s. 7

22 Tak też J. F. Godlewski, op. cit., s. 161, oraz K. Grzybowski, B. Sobolewska, op. cit., s. 60.

${ }^{23}$ Papież dopowiadał, że: „Znaczenie prawa może dotrzeć do przykazania ludzkiego rozumu, bowiem prawo to jest głosem i tłumaczem każdego wyższego rozumu, któremu nasz duch i nasza wolność mają być posłuszne. Ponieważ siła prawa składa się z nakładania obowiązków i wydawania, stanowienia praw, (więc) polega ona całkowicie na a u t o r y t e c i e, tzn. w istotnej sile zarówno na ustalaniu obowiązków i praw, jak i - poprzez karę i nagrodę - na ustalaniu sankcji dla nakazów. Jest jasnym, iż to wszystko nie mogłoby się zdarzyć człowiekowi (w człowieku), gdyby nie było Boga, który jako najwyższy prawodawca dał mu (człowiekowi) dla jego działań tę normę. Stąd wynika, iż prawo natury jest jednym i tym samym, czym p raw o wi e c zne, które przyrodzone jest istotom rozumnym i prowadzi je do takiego działania, które odpowiada celowi człowieka; jest to mianowicie sam wieczny rozum Boga, Stwórcy i „kierownika” całego świata.”, por. 'Libertas praesstantissimum'; [w:] 'Lumen de Caelo'..., s. 100-101.

${ }^{24}$ Tamże, s. 100. Leon XIII stwierdzał wprost : „Z początku potrzebne więc było p r a w o, każda reguła na to, co można robić a czego nie; o nim (o prawie) nie może być mowy przy wszelkich istotach żyjących, które działają pod wpływem konieczności, bowiem takie istoty przy każdej swej czynności podążają za popędem natury. Istoty rozważne natomiast, z racji posiadania wolności, mają prawo do działania bądź niedziałania albo do całkiem innego działania; wybierają to, co chcą, a to poprzedza 
bowiem „człowiek musi być prowadzony przez prawo, ponieważ jest on z natury wolny"25.

Z kolei wypowiedzi papieskie zawarte w encyklice przeciwko socjalizmowi - Quod Apostolici muneris ${ }^{26}$ (z 1878 r.) często odwoływały się do prawa naturalnego i prawa bożego, jako fundamentów religii katolickiej, których przestrzeganie gwarantuje bezpieczeństwo w życiu rodzinnym i publicznym. Zgodnie z zasadami tego prawa należy szanować prywatną własność i odrzucić naturalną równość wszystkich ludzi ${ }^{27}$.

każdy (o)sąd rozumu. Ten osąd nie tylko mówi o tym, co bliskie (zwyczajowe) jest naturze, a co oddalone od niej, lecz także to, co dobre i co należy czynić, jak też co złe i czemu należy zapobiegać. Rozum bowiem wytycza, wskazuje woli po co może ona sięgać, czego może pragnąć, a czego nie, aby człowiek mógł osiagnąć z czasem swój ostateczny cel, pod kątem którego wszystko musi być uporządkowane. Ten porządek rozumu nazywa się prawem”.

25 Tamże.

${ }^{26}$ Encyklika papieża Leona XIII 'Quod Apostolici muneris' - o sekcie socjalistów, komunistów i nihilistów, z 28 grudnia 1878, Warszawa 2002 (dalej: Quod Apostolici muneris). Papież wielokrotnie odnosił się do wiodących ideologii politycznych XIX wieku, wykładając stanowisko Kościoła zwłaszcza wobec socjalizmu, masonerii i liberalizmu, ponieważ wymienione ideologie wywarły szczególny wpływ na rozwój myśli politycznej w ubiegłym stuleciu. Doktryny te stały się przedmiotem odrębnych encyklik Leona XIII. Wzmiankowana Quod Apostolici muneris zawierała ostrą krytykę socjalizmu, dokonaną niespełna 11 miesięcy po objęciu przez jej autora apostolskiego urzędu, co świadczyło o tym, że papież doceniał wagę problemu. Por. też R.L. CAMP, The Papal Ideology of Social Reform: A Study in Historical Development 1878-1967, Leiden 1969, s. 51-52.

${ }^{27}$ Leon XIII pouczał, że „Mądrość katolicka, kierując się przykazaniami prawa naturalnego i bożego, przyczynia się także najrozsądniej do pokoju w rodzinie i w życiu publicznym, przez swoje przekonania i nauczanie o prawie sprawowania władzy i podziale dóbr przeznaczonych dla zachowania i pożytku życia. Socjaliści uważają prawo własności za ludzki wymysł niedający się pogodzić z przyrodzoną równością ludzi, głoszą więc wspólność dóbr, nie godzą się na znoszenie bez sprzeciwu niedostatku i uważają, że można bezkarnie naruszać własność i prawa bogatszych. Kościół natomiast uznaje trzeźwiej, że między ludźmi nie ma równości przyrodzonej pod względem sił i zdolności, a więc nie ma jej także pod względem posiadanych dóbr, i dlatego nakazuje, by prawo własności i zwierzchnictwa urzeczywistnione przez samą naturę pozostawało dla każdego nietknięte i nienaruszone", Quod Apostolici muneris, s. 13. 
Należy zatem przyjąć, że Leon XIII w swojej koncepcji prawa szeroko, ale jednocześnie twórczo czerpał $\mathrm{z}$ dorobku wypracowanego przez św. Tomasza z Akwinu i podobnie jak ten średniowieczny teolog dzielił prawo na: prawo boże, prawo naturalne i prawo pozytywne, to jest prawo ustanowione przez uprawnione do tego organy państwa ${ }^{28}$.

Wypada dopowiedzieć, że w dobie pontyfikatu Leona XIII, zatem na przełomie XIX i XX stulecia idea praw człowieka znalazła uznanie jedynie w prawodawstwie nielicznych państw europejskich ${ }^{29}$, np. w konstytucji Królestwa Belgii z 7 lutego 1831 r. oraz Konfederacji Szwajcarskiej z 29 maja 1874 r. ${ }^{30}$ Warto bowiem pamiętać, że dopiero druga połowa XX wieku przyniosła pełne uznanie analizowanej kategorii ${ }^{31}$. Papieskie koncepcje, oczywiście w sposób pośredni, korespondowały z takimi, wcześniejszymi o stulecie, aktami prawnymi jak: Deklaracja Praw Wirginii z 12 czerwca 1776 r., amerykańska Deklaracja Niepodległości z 4 lipca 1776 r., czy francuska Powszechna Deklaracja Praw człowieka i Obywatela z 26 sierpnia 1789 r. Wymienione dokumenty głosiły m.in.: że wszyscy ludzie są z natury równi, wolni i niezależni, oraz posiadają pewne przyrodzone prawa: prawo do własności, bezpieczeństwa i oporu przeciwko uciskowi ${ }^{32}$.

28 Tak też J. F. GodlewsKi, op. cit., s.160.

${ }^{29}$ Należy podzielić pogląd P. BaŁy i A. Wielomskiego, Prawa człowieka i ich krytyka. Przyczynek do studiów o ideologii naszych czasów, Warszawa 2008, s. 41, że w XIX wieku koncepcja praw człowieka poszła w zapomnienie nawet we Francji.

${ }_{30}$ Por. M. ŁopatKa, Międzynarodowe prawo praw człowieka. Zarys, Warszawa 1998, s. 11-12.

${ }^{31}$ M. Freeman, Prawa czlowieka, Warszawa 2007, s. 42, nie zawahał się stwierdzić, że po 10 grudnia 1948 r. (data przyjęcia przez ONZ Powszechnej Deklaracji Praw Człowieka), prawa człowieka stały sięjednąz najbardziej nośnych idei we współczesnej polityce.

32 Por. Deklaracja Praw Wirginii z 12 czerwca 1776 r., amerykańska Deklaracja Niepodległości z 4 lipca 1776 r., [w:] Powszechna historia państwa i prawa. Wybór tekstów źródtowych. Wydanie drugie rozszerzone, wyboru dokonali M.J. РТAK i M. KunstLer, Wrocław 1996, s. 63, 328-331. 
W moim przekonaniu uprawniona jest, a prima vista mocno kontrowersyjna teza, że prawa te, rozumiane po katolicku, występują także w nauczaniu następcy Piusa IX.

Przystępując do analizy naturalnych praw człowieka w nauczaniu tego papieża, chciałbym zaakcentować, że zaliczam do nich przede wszystkim prawo do: życia, równości, wolności, bezpieczeństwa, oporu przeciwko uciskowi i własności. Zastrzegam jednak, że również niektóre inne prawa należy umieścić w tej grupie.

Leon XIII jedynie w sposób marginalny zajmuje się prawem człowieka do życia, albowiem w jego epoce prawo to było przyjmowane bezdyskusyjnie. W swojej najgłośniejszej encyklice Rerum novarum jej autor stwierdził, że człowiek nie otrzymuje tego prawa od państwa, bowiem człowiek jest „starszy” od państwa i ,posiadał prawo do zachowania swego życia cielesnego, zanim jeszcze istniało państwo"33.

Warto podkreślić, że papieskie wypowiedzi dotyczące kategorii równości są dosyć liczne ${ }^{34}$, albowiem już jedna z pierwszych papieskich encyklik, wspomniana wcześniej Quod Apostolici muneris, poruszała tę kwestię. W tej enuncjacji papież wykorzystał koncepcję godności człowieka, by odrzucić hasła głoszące naturalną równość wszystkich ludzi ${ }^{35}$. W jego ocenie postulowana przez przeciwników Kościoła wersja tej idei, mówiąca, że wszyscy są z natury sobie równi, wzywa do

${ }^{33}$ Rerum novarum, s. 5.

${ }^{34}$ Papież odnosił się do tej kategorii m. in. w encyklikach: Quod Apostolici muneris, Rerum novarum, In plurimis, Humanum genus.

${ }^{35}$ Godzi się zauważyć, że w społecznej nauce Kościoła koncepcja równości obejmuje trzy wymiary: ontologiczny, prawny i ekonomiczny. Refleksja nad wymiarem ontologicznym ukazuje, że podstawą równości społecznej jest godność osoby ludzkiej, a godność ta, jak zauważył papież Jan XXIII, wskazuje, iż „każdy człowiek jest osobą, to znaczy istotą obdarzoną rozumem i wolną wolą, wskutek czego ma prawa i obowiązki, wypływające bezpośrednio i równocześnie z własnej jego natury. Jeśli zaś spojrzymy na godność osoby ludzkiej w świetle prawd objawionych przez Boga, to będziemy musieli niewątpliwie ocenić ją znacznie wyżej... . Ludzie zostali bowiem odkupieni za cenę krwi Jezusa Chrystusa, stali się mocą łaski Bożej dziećmi i przyjaciółmi Boga i zostali ustanowieni dziedzicami chwały wiecznej, por. Jan XXIII, Encyklika 'Pacem in terris' z 11 kwietnia 1963 r., o pokoju między wszystkimi narodami opartym na prawdzie, sprawiedliwości, miłości i wolności, Wrocław 1997, 9-10. 
braku szacunku dla władzy i każdego prawa, poza tym, które wypływa z umowy społecznej ${ }^{36}$. Natomiast według papieża Ewangelia głosi, że „równość ludzi polega na tym, że posiadając wszyscy tę samą naturę, są powołani do najwznioślejszej godności synów Bożych, i mając wszyscy wyznaczony ten sam cel, będą pojedynczo sądzeni według tego samego prawa, otrzymując według zasług karę lub nagrodę" "37. Tym samym możemy zauważyć, że Leon XIII przywołuje tutaj biblijny argument imago Dei w celu uzasadnienia godności i równości wszystkich ludzi ${ }^{38}$.

Również w encyklice In plurimis $^{39}$ - o niewolnictwie papież przekonywał, że to dzięki chrześcijaństwu została wprowadzona prawdziwa wolność, braterstwo i równość wśród ludzi, co przyczyniło się do lepszego rozwoju narodów ${ }^{40}$.

${ }^{36}$ Odnośnie krytycznego stosunku Leona XIII do koncepcji umowy społecznej por. szerzej M. SAdowski, Państwo w doktrynie papieża Leona XIII..., s. 103.

${ }^{37}$ Quod Apostolici muneris, s. 9.

38 Szerzej na ten temat por. E.C. GARDNER, Justice and Christian Ethics, CambridgeNew York 1995, s. 132, który stwierdził, że Leon XIII transcendentną godność osoby ludzkiej wywodzi z zasady imago Dei, a także M. J. McDonough, Can a Health Care Market Be Moral?: A Catholic Vision, Washington D.C. 2007, s. 15.

39 Encyklika papieża Leona XIII 'In plurimis' - o niewolnictwie do 5 maja 1888 r., por. http://www.vatican.va/holy_father/leo_xiii/encyclicals/documents/hf_l-xiii_enc_ 05051888_in-plurimis_en.html.

40 Tamże. Co znamienne, osiem dni po jej ogłoszeniu, 13 maja 1888 r., brazylijski parlament uroczyście przegłosował tzw. złote prawo, uwalniające ok. 750 tys. niewolników żyjących jeszcze wówczas w kraju. Brazylia zniosła niewolnictwo jako ostatni kraj amerykański, nie można wykluczyć, że pewną rolę w tej kwestii odegrało stanowisko Kościoła katolickiego. W analizowanym dokumencie jego autor przypomniał wysiłki podejmowane przez Kościół na rzecz zniesienia „zarazy” niewolnictwa. Dopiero nastanie chrześcijaństwa przyniosło inne spojrzenie na niewolnictwo. Dzięki Chrystusowi niewolnicy uzyskali lepszy status, stając się chrześcijanami, byli doprowadzani do „najznakomitszej godności dzieci Bożych”, TAmżE. Papieskie wypowiedzi dotyczące analizowanych kwestii znaleźć możemy także w liście apostolskim Annum ingressi sumus z 19 marca 1902 r. Por. testament Leona XIII z 19 marca 1902 r., 'Annum ingressi sumus', [w:] Lumen de Caelo..., s. 3-21. 
Swoje rozumienie równości wyłożył także w encyklikach Humanum genus $^{41}$ - o masonerii i Libertas praestantissimum ${ }^{42}$. W tym pierwszym dokumencie nauczał o równości, która oparta na sprawiedliwości i miłości, nie usuwa wszystkich różnic między ludźmi, lecz z różnorodności sposobów życia, obowiązków i uzdolnień tworzy zgodną i harmonijną całość, która ze swej natury służy pożytkowi i podnosi godność społeczeństwa ${ }^{43}$. Z kolei w Libertas praesstantissimum dopowiadał, z powołaniem się na Pismo Święte, że równość wobec prawa, prawdziwe braterstwo między ludźmi głosił jako pierwszy Jezus Chrystus, a za nim Apostołowie nauczając, że ,nie masz Żyda, ani Greka, ani barbarzyńcy, ani Scyty, lecz wszyscy są braćmi w Chrystusie ${ }^{44}$. W poglądach papieża dostrzec można wyraźne podkreślenie przez niego przełomowego wpływu chrześcijaństwa na właściwe rozumienie idei równości pomiędzy ludźmi.

Niezwykle istotną rolę w pojmowaniu przez Leona XIII kategorii równości odegrała papieska koncepcja godności człowieka, najpełniej zaprezentowana w encyklice Rerum novarum. Odwołując się do osoby Jezusa Chrystusa, papież pouczył, że prawdziwa godność człowieka i jego wyższość polega na cnocie, cnota zaś dostępna jest zarówno wielkim, jak i dla maluczkim, dlatego też zarówno bogaci, jak ubodzy moga ją posiąść ${ }^{45}$. Papież dopowiedział nawet, że kiedy wszyscy dostrzegą, że są stworzeni przez jednego Boga - że wszyscy dążą

41 'Humanum genus', Encyklika O masonerii z 20 kwietnia 1884 r., Jego Światobliwości pana naszego Leona XIII z opatrzności Bożej papieża, [w:] G. VIREBEAU, Papieże wobec masonerii, Komorów 1997, s. 73-103.

42 Encyklika papieża Leona XIII 'Libertas praestantissimum' [w:] Lumen de Caelo..., s. 96-119.

${ }^{43}$ Humanum genus, s. 79.

44 'Libertas praesstantissimum', [w:] Lumen de Caelo..., s. 99.

${ }^{45}$ Rerum novarum, s. 17. Por. też J. Courtney Murray, Religious Liberty: Catholic Struggles with Pluralism, ed. J. L. Hooper, Louisville, Kentucky 1993, s. 206; a także J. Wronka, Human Rights and Social Policy in the 21st century: A History of the Idea of Human Rights and Comparison of the United Nations Universal Declaration of Human Rights with United States Federal and State Constitutions, Lanham, Maryland 1998, s. 82. 
do tego samego celu, do Boga, który sam jeden może dać doskonałą i pełną szczęśliwość ludziom, a ponadto że wszyscy na równi odkupieni zostali przez Jezusa Chrystusa i podniesieni przez Niego do godności dzieci Bożych, zrozumieją że łączy ich prawdziwe braterstwo między sobą oraz z Chrystusem ${ }^{46}$. Godzi się zauważyć, że papieska aprobata dla ludzkiej godności ma uzasadnienie teologiczne, wypływa ona wprost z ewangelicznego nauczania twórcy chrześcijaństwa, Jezusa Chrystusa o równej, ontologicznej godności wszystkich ludzi jako dzieci Bożych.

W kwestii prawa do oporu przeciwko uciskowi papież pouczył chrześcijan, że powinni być posłuszni każdej władzy, nawet takiej która postępuje bezprawnie, a sprzeciwić mogą się dopiero wtedy, gdy władza ustawodawcza lub wykonawcza podejmie działania bądź wyda decyzje sprzeczne z prawem bożym lub naturalnym ${ }^{47}$, albowiem ,godność i obowiązek chrześcijańskiego imienia, a także wskazania apostolskie zalecają, by bardziej słuchać Boga niż ludzi" ${ }^{48}$. W mojej ocenie koncepcja godności człowieka (chrześcijanina) posłużyła autorowi encykliki za argument uzasadniający prawo do oporu wobec władzy łamiącej prawo boskie lub naturalne.

Analizując prawo człowieka do bezpieczeństwa można przywołać nauczanie Leona XIII o społecznym prawie człowieka do życia w pokoju. Problem ten został przedstawiony przez papieża po raz pierwszy w mowie wygłoszonej do kardynałów na konsystorzu w dniu 11 kwietnia 1889 r. ${ }^{49} \mathrm{~W}$ wypowiedzi tej zwrócił on uwagę na inny niż

46 Tenże, s. 17. Jak zauważył D.P. McCANN, The common good in catholic social teaching. A case study in modernization, [w:] In Search of the Common Goods, ed.: D. McCann, P. D. Miller, New York 2005, s. 127, w encyklice papież broni ludzkiej godności i praw robotników.

47 Jak stwierdził B. Szlachta, Leonowi XIII bliska była interpretacja prawa naturalnego, rozumianego jako system norm precyzyjnie określających życie człowieka we wszystkich obszarach jego aktywności, B. SzLachta, Wokół katolickiej myśli politycznej, Kraków 2008, s. 219.

${ }^{48}$ Quod Apostolici muneris, s. 11.

49 Por. J. Kondziela, Pokój w nauce Kościoła. Pius XII-Jan Paweł II, Lublin 1992, s. 73. 
w przeszłości charakter współczesnej wojny. Odwołując się do prawa narodów do słusznej obrony / teoria wojny sprawiedliwej / wskazał na wyraźne dysproporcje pomiędzy zamierzonymi celami, a rzeczywistymi skutkami wojny. $\mathrm{Z}$ tych powodów potępił modernizację i rozbudowywanie armii ${ }^{50}$ i wezwał do stworzenia nowego porządku międzynarodowego, opartego na zasadach sprawiedliwości i miłości chrześcijańskiej ${ }^{51}$. Wzywając do zachowania tych zasad i apelując o niemal powszechne rozbrojenie, bowiem łatwe są do przewidzenia konsekwencje współczesnej wojny, Leon XIII opowiedział się pośrednio za prawem człowieka do życia w pokoju, przestrzegając, że w przeciwnym razie Europę czekają ,„straszne klęski”"52.

Powrócił do tej kwestii w encyklice Praeclara gratulationis /Kościół i narody świata/ z 1894, w której stwierdzał, że od wielu już lat żyjemy w pokoju bardziej pozornym niż rzeczywistym, a wszystkie narody, nękane bezustannie podejrzeniami, prześcigają się w przygotowaniach wojennych ${ }^{53}$. Wskazując na tragiczne konsekwencje ekonomiczne takiej sytuacji, ogromne sumy przeznaczone na zbrojenia, oderwanie milionów ludzi od pracy produkcyjnej, trudności w dziedzinie finansów publicznych przedstawiał sposób rozwiązania tego problemu. Aby utrzymać pokój należy w przekonaniu Leona XIII zwrócić się ku „,notom chrześcijańskim, a zwłaszcza sprawiedliwości, oraz „zachować wiarę w traktaty" ${ }^{\prime 2}$. Analiza powyższych wypowiedzi papieskich upoważnia do postawienia tezy, że prawo człowieka do życia w pokoju nie

${ }^{50}$ We wzmiankowanym wystapieniu stwierdził: Groźne pomnażanie zasobów broni może nawet bardziej sprzyjać pobudzeniu niż przekreśleniu rywalizacji i podejrzeń. Wprowadza do umysłów zamęt związany z trwożliwym oczekiwaniem na przyszłe wydarzenia i stwarza tę rzeczywistą niedogodność, iż nakłada na ludzi brzemię tak wielkie, że można wątpić by było znośniejsze niż wojna, cyt. za G. MinoIs, Kościót i wojna. Od czasów Biblii do ery atomowej, Warszawa 1998, s. 373.

51 J. KonDZIELA, op.cit., s. 74.

52 G. MinoIs, op.cit., s. 373.

${ }_{53}$ Por. Leon XIII, Encyklika 'Praeclara gratulationis' z 20 czerwca 1894 r., [w:] Lumen de Caelo..., s. 52-53.

${ }^{54}$ Tamże, s. 65. 
zostało sformułowane przez papieża wprost, lecz przedstawione jedynie w sposób pośredni.

W kwestii wolności należy stwierdzić, że w sposób systematyczny i kompleksowy Leon XIII zajął się tym problemem w encyklice Libertas praestantissimus z 20 czerwca $1888 \mathrm{r}^{55}$ Znane są jednak również jego wcześniejsze wypowiedzi na ten temat, albowiem już w encyklice Immortale Dei z 1885 r. papież stając w obronie prawowitej władzy potępiał głosicieli „rozpasanej wolności”. Według Leona XIII Kościół „nie może pochwalać tej wolności, która pomiata świętością Boskich praw i należne prawowitej władzy wypowiada posłuszeństwo". Taka wolność nie jest żadną wolnością, bardziej przypomina swawolę niż wolnośćs ${ }^{56}$ Leon XIII potępiał niczym nie skrępowaną wolność przekonań i nieograniczoną wolność prasy. Jego zdaniem „Wolność jako przymiot doskonalący człowieka, powinna się w sferze prawdy i dobra obracać", a te są przecież niezmienne i trwałe i dlatego nie zależą od ludzi ${ }^{57}$. Państwo powinno chronić swoimi prawami rozmaite przejawy wolności, jeżeli chce działać zgodnie ze zdrowym rozsądkiem. Dokonując rozróżnienia między prawdziwą i fałszywą wolnością następca św. Piotra zdecydowanie wypowiadał się za tą pierwszą. Bowiem ,prawdziwa wolność” zarówno w życiu prywatnym jak i publicznym ,... mądrze obywatelom przewodniczy i szeroką daje im w sferze dobra swobodę działania, a zarazem broni państwa od obcej przemocy". Taką właśnie wolność Kościół akceptuje $^{58}$. Podsumowując swoje wywody dotyczące wolności zawarte w omawianej encyklice, papież stwierdził, iż Kościół „,Z jednej strony odrzuca nadmierną wolność, która tak u jednostek jak u narodów,

${ }^{55} \mathrm{~W}$ oficjalnych dokumentach papieskich encyklika ta zatytułowana jest: „Kościół i wolność człowieka”, por. Lumen de Caelo..., s. 120.

${ }^{56}$ Por. Encyklika Ojca Świętego Leona XIII, O chrześcijańskim ustroju państw, (tak w oficjalnych dokumentach papieskich nazywana jest encyklika Immortale Dei), przekład i wydanie Przegladu Powszechnego, Kraków 1886, s. 24 i n. Zdaniem Leona XIII korzenie tej „wyuzdanej wolności” sięgają XVI wieku, czyli reformacji, tamże, s. 18.

\footnotetext{
57 Tamże, s. 21.

58 Tamże, s. 25.
} 
albo w swawolę się przeradza, albo w niewolę, z drugiej strony skłania się chętnie ku ulepszeniom, jakie dzień każdy przynosi, byle prawdziwie służyły pomyślności niniejszego życia, pola zasług i wędrówki do wieczności" ${ }^{59}$. Rozwijając nieco dalej wątek dotyczący nowoczesności i postępu, Leon XIII podkreślił, że Kościół nie odrzuca nowoczesnych, ale prawych to jest zgodnych z nauką Kościoła rozwiązań, jakie przynosi współczesność, a ponadto pragnie „dla spraw publicznych bezpieczniejszych dróg i trwalszych podwalin przy zachowaniu prawdziwej ludów wolności, albowiem matką i orędowniczką najlepszą wolności ludzi jest prawda" ${ }^{60}$. Cytując dalej słowa św. Jana „Prawda was wyswobodzi" ${ }^{\prime \prime 1}$ akcentował, że prawda odkrywana przez ludzki intelekt nie może wchodzić w konflikt $\mathrm{z}$ prawdami objawionym ${ }^{62}$.

Jak wspomniałem wcześniej w szerokim kontekście problemem wolności zajął się Leon XIII w encyklice Libertas praestantissimum $^{63}$. Już w zdaniu otwierającym encyklikę „O wolności ludzkiej” papież nazywa wolność „najwyższym dobrem natury” ${ }^{64}$ i podkreśla, że Kościół od początku swego istnienia strzeże tego najcenniejszego dla ludzi skarbu ${ }^{65}$. Problem tkwi jego zdaniem, jedynie w tym jak ową

59 Tamże.

${ }^{60}$ Tamże, s.26.

${ }^{61}$ Tamże. Interesujące rozważania na temat wzajemnych relacji prawdy i wolności, por. R. Simon, Ogólna teoria władzy, Kraków 1998, ss. 60-99.

${ }^{62} \mathrm{~W}$ tym duchu por. też H. OlszewsKi, Władza i społeczeństwo w nauczaniu Leona XIII, «Życie i Myśl», 59.5-6/1991, s. 19.

${ }^{63} \mathrm{~W}$ niemieckim wyborze dokumentów ogłoszonych przez papieża Leona XIII, encyklika ta nosi tytuł: „Die Kirche und die menschlische Freiheit”, por. 'Lumen de Caelo', Erweiterte Ausgabe des „Leo XIII. der Lehrer der Welt”. Praktische Ausgabe der wichtigsten Rundechreiben Leo XIII. und Pius XI. in deutscher Sprache mit Übersicht und Sachregister. Hrg. C. UlitzKa, Ratibor 1934. Podobnie nazywa ją A. Rembowski, Encyklika o wolności ludzkiej (z d. 20 czerwca 1888 r.), [w:] Leon XIII. Żywot i prace. Z illustracyami, Warszawa 1902, s. 284.

${ }^{64}$ „Praestantissimum naturae bonum”, por. P. PopIEL, Leon XIII i papiestwo w objawach zewnętrznych, Kraków 1910, s. 27, w thumaczeniu niemieckim: „Die Freiheit, diese äusserst wertvolle habe der Natur", por. Lumen de Caelo..., s. 96.

65 Tamże. 
wolność należy pojmować. Papież wychodzi z teologicznego pojęcia wolności przedstawionego w Nowym Testamencie oraz koncepcjach św. Augustyna i św. Tomasza z Akwinu ${ }^{66}$. Zgodnie z tym założeniami człowiek to istota ze swojej natury rozumna, a więc tym samym wolna. Należy przez to rozumieć, że nie może on być w inny sposób kierowany do celu, jak tylko poprzez swoje własne swobodne działanie. Dzięki temu jest panem swoich czynów, jest wolny ze swej istoty. Zdaniem J. Majki, tak pojmowana wolność „może być nazwana wolnością transcendentna, bo pozostaje w transcendentalnym stosunku do natury ludzkiej jako jej istotna właściwość". Takie rozumienie wolności ma charakter absolutny i nie podlega żadnemu ograniczeniu, które nie byłoby naruszeniem ,elementarnej struktury ludzkiej natury" ${ }^{\prime 67}$.

Wobec powyższego, z punktu widzenia chrześcijaństwa, wolność w swej istocie nie jest prawem człowieka, lecz sposobem jego duchowego istnienia i działania, polegającym na tym, że ,jest on w stanie kierować się do najwyższych wartości, zdolnych go dopełnić i udoskonalić do prawdy i dobra. Dlatego w pojęciu wolności mieści się zawsze odniesienie do prawdy i dobra jako celu ludzkiego dążenia"68. Po uznaniu wolności za najwyższe dobro Leon XIII stwierdził, że ta „norma i reguła wolności, opiera się na wiecznym prawie bożym, a nie na przepisach tego lub owego człowieka, lub nawet społeczeństwa ludzkiego" ${ }^{" 69}$. Z tego względu w społeczeństwie ludzkim prawo wolności, nie

${ }^{66}$ Szerzej w tej kwestii por. M. SADowsKI, Koncepcja wolności w nauczaniu papieża Leona XIII, «Przegląd Prawa i Administracji» 44/2000, s. 85-88.

${ }^{67}$ J. MaJKA, Etyka społeczna i polityczna, Warszawa 1993, ss.35-36. Szerzej na temat chrześcijańskiej koncepcji wolności por. TenżE, Chrześcijańska koncepcja wolności a prawo do wolności, «Znak»19/1967, a ponadto: J. B. METz, Freiheit als philosphischtheologisches Grenzproblem, [w:] Gott in Welt, Festgabe für Karl Rahner, Freiburg i B. 1964, B.I.

68 J. MAJKA, op.cit., s. 36. por. też: Instrukcjęo chrześcijańskiej wolności i wyzwoleniu, z 22 marca 1986 r, opracowaną przez watykańską Kongregację Nauki Wiary, Wrocław 1986, ss.47, a zwłaszcza P. Tischleder, Die Staatslehre Leos XIII, M. Gladbach 1925 , ss. $18-25$.

${ }^{69}$ Encyklika 'Libertas praestantissimum', [w:] Władza. Wolność, Prawo. Wybór tekstów z historii doktryn politycznych dla studiujacych prawo, nauki polityczne i filozofię, Kraków 1994, s. 181. 
polega na tym, aby każdy robił to co tylko zechce, bo to doprowadziłoby do większego zamętu i zamieszania, ,... wskutek czego państwo runąc by musiało...", lecz przeciwnie, prawo wolności polega na tym, aby z pomocą praw świeckich człowiek mógł łatwiej dostosować się do przepisów tego wieczystego prawa ${ }^{70}$. Ta reguła działa w obie strony i dotyczy nie tylko rządzonych, ale również rządzących. Jak podkreślił Leon XIII: „Wolność zaś przełożonych i władz nie na tym polega, aby mogli rozkazywać lekkomyślnie i według swej samowoli - gdyż to byłoby zbrodnią... Moc i potęga praw ludzkich to być powinna, iżby łatwo poznać można, że wypływają z prawa wiecznego"ᄁ1. To wyraźne powiązanie wolności z prawem jest charakterystyczne od jej początków dla chrześcijańskiej koncepcji wolności, również tej z drugiej połowy XX wieku, a więc już po Soborze Watykańskim II, którego deklaracja o wolności miała znaczenie przełomowe ${ }^{72}$.

Natura wolności ludzkiej, pouczał papież, „... wskazuje nam konieczność poddania się najwyższemu i wiecznemu rozumowi, który nie jest niczym innym, jak powagą rozkazującego i zakazującego Boga. Ta zaś najsłuszniejsza władza rozkazywania Pana Boga nie tylko wolności człowieka nie znosi ani jej w żaden sposób nie zmniejsza lecz przeciwnie, tę wolność broni i jeszcze ją doskonali. Osiagnąć bowiem cel, do którego się zmierza, jest najwyższą doskonałością każdej istoty; najwyższym zaś celem, do którego wolność człowieka dążyć powinna jest Bóg" 73 .

Następnie autor encykliki odniósł się do liberalnej koncepcji wolności, akcentując, że jej sprzeciw wobec nauczania Kościoła katolickiego

70 Tamże, s. 181-182.

71 Tamże.

72 Wszak wybitny niemiecki myśliciel E.-W. BöCKENFÖRDE, Wolność i prawo, wolność i państwo, [w:] Wolność - Państwo - Kościót, Kraków 1994, s. 151, napisał: „Prawo musi zawierać w sobie wolność. To jest właściwe (filozoficzne) pojęcie prawa. Dopiero gdy odpowiada mu prawo empiryczne wówczas staje się ono koniecznym i wystarczającym warunkiem wolności”.

73 'Libertas praestantissimum', [w:] Władza. Wolność, Prawo..., s.182. Por. też E. Schockenhoff, Naturrecht und Menschenwürde. Universale Ethik in einer geschichtlichen Welt, Mainz 1996, s. 47. 
wynika z faktu niezrozumienia przez liberałów czym jest ,sprawiedliwa i uczciwa" wolność. Liberalne pojmowanie wolności zakłada bowiem, zdaniem papieża, niezależność od boskich przykazań, czego konsekwencją może być „samowola bez granic"74.

W dalszej części analizowanej enuncjacji Leon XIII omawia poszczególne „rodzaje” wolności. Rozpoczyna od „tak zwanej (słowa encykliki) wolności wyznania, opierającej się na zasadzie, że każdemu wolno jest wyznawać religię, która mu się podoba albo w ogóle jak to mówią - być bezwyznaniowym" 75 . Autor encykliki zdecydowanie odrzuca ten pogląd i to zarówno na gruncie prywatnoprawnym jak i publicznoprawnym. Stwierdził bowiem, powtarzając za św. Tomaszem, że ,religia sprawia to, co wprost skierowane jest ku chwale Boga, jest panią i kierowniczką cnót wszystkich", a przecież bez religii, pisze papież, człowiek żadną miarą nie może zdobyć się na cnotę". Z tych powodów człowiek nie może sobie dowolnie wybierać religii, bo to doprowadzi do „zepsucia wolności i niewoli ducha do grzechu się skłaniającego". Człowiek powinien wybrać tę religię, którą wskaże mu Opatrzność Boża ${ }^{76}$. Owa wolność zdaniem Leona XIII, nie może być rozumiana również w ten sposób, że państwo żadnej religii nie uznaje za religię państwową, albowiem religia niesie ze sobą znaczące korzyści dla państwa ${ }^{77}$. W analizowanym dokumencie papież zajmował się również prawem do wolności wyrażania swej opinii - to jest wolnością prasy i nauczania. Prasa według Leona XIII, ,jest zdolnością moralną, byłoby (zatem) rzeczą nierozsądną mniemać, że ta zdolność moralna tak samo prawdzie, jak i kłamstwu, zacności i brzydocie bez różnicy i ogólnikowo od natury przyznana została". Podkreślał, że nie ograniczone normami moralnymi prawo głoszenia swych poglądów może być nadużywane do wywierania nacisku na innych i propagowania fałszu. Opowiadał się za tym, żeby ,... to co jest prawdą oczywistą to wolno jest rozsądnie w państwie rozszerzać, ... natomiast fałszywe

\footnotetext{
74 'Libertas praestantissimum', [w:] Władza. Wolność, Prawo..., 182-183.

75 Tamże.

76 Tamże, s. 185.

77 Tamże, s. 186. Por. też A. Rembowski, Encyklika o wolności ludzkiej..., s. 285.
} 
i kłamliwe opinie ... powinno państwo publiczną swoją powagą trzymać w należytych karbach". W przeciwnym bowiem razie pozostawiwszy człowiekowi „wolność mówienia i pisania co mu się podoba, nie pozostanie nic świętego i nietykalnego ... i łatwo rozliczne błędy na świecie zapanują”, dlatego prawdziwa wolność, tym „większą i pewniejszą będzie im silniejsze wędzidła na swawolę nałożone zostaną ${ }^{78}$. Jak wynika z powyższych słów, głoszenie fałszu, zdaniem papieża, nie jest żadnym prawem, gdyż byłoby prawem upowszechniania zła, a takiego prawa nikomu nie można przyznać. W sposób analogiczny ujmuje papież prawo do wolności nauczania. Odnosi się ona tylko do nauczania prawdy. Poglądy głoszone przez Leona XIII, a dotyczące wolności prasy i nauczania stały w wyraźnej sprzeczności wobec haseł głoszonych przez ówczesny liberalizm, a nawet do zapisów konstytucyjnych (np. art. 44 Konstytucji USA).

Odnosząc się do wolności sumienia (wyznania, religii), wypowiedzi i nauczania papież wyraża pogląd, że doktryna Kościoła w tych dziedzinach „nie tylko dla zbawienia dusz jest konieczną”, ale zgodne postępowanie Kościoła i państwa, tych dwóch jedynych fundamentów życia społecznego uważa za cel, do którego należy dążyć ${ }^{79}$. Zdaniem Leona XIII „nie wolno żądać, bronić, udzielać wolności myślenia, pisania, nauczania ani wolności religijnej jako tyluż praw człowiekowi przez naturę przyznanych. Albowiem gdyby natura człowiekowi takie prawo rzeczywiście była przyznała, mielibyśmy [wówczas] prawo uwłaczać najwyższej władzy Pana Boga, a wolność ludzka nie znałaby i nie cierpiała żadnych w ogóle granic" ${ }^{\text {" }}$. Z powyższych słów wynika, iż papież Leon XIII był w znacznej mierze kontynuatorem tradycyjnej, chrześcijańskiej nauki o wolności w rozumieniu św. Augustyna i św. Tomasza z Akwinu. Istotne novum jakie wprowadził, wyrażają zdania następujące zaraz po przytoczonych przeze mnie wyżej: „Wynika z tego, że ,... owe rodzaje wolności (wyznania, myślenia, naucza-

${ }^{78}$ Encyklika 'Libertas praestantissimum', Władza. Wolność, Prawo..., s. 186. por. też J. F. MazureK, op. cit., s.34.

79 P. Popiel, op. cit., s. 29.

${ }^{80}$ Encyklika 'Libertas praestantissimum', [w:] Władza. Wolność, Prawo..., s. 188. 
nia, - przyp. M. S.) mogą z ważnych przyczyn być tolerowane, z tym wszelako zastrzeżeniem, iżby się nie wyradzały w namiętność lub zuchwałość..." wolności, do wykorzystywania jej do godziwych czynów. Uważał on bowiem, że wolność może być uznana za prawowitą tylko wtedy, gdy daje „możliwość osiagnięcia rzeczy zacnych i uczciwych, w pozostałym zaś zakresie - nigdy" ${ }^{2}$.

Wypada podzielić pogląd A. Rembowskiego, iż encyklika, Libertas, uznała różnego rodzaju wolności, pod warunkiem, że odpowiedni „hamulec prawny", to jest zespół zakazów ustanowiony przez państwo nie pozwoli im przeistoczyć się w „absurdalną samowolę”, prowadzącą do grzechu. Wolność bowiem tylko wtedy może być uznana za uprawnioną, jeśli pomnaża w nas wolność czynienia doba ${ }^{83}$.

W papieskiej ocenie wolność odzwierciedla zasadę hierarchii wartości dotyczącą Boga, świata i człowieka, i dlatego każdy człowiek powinien sobie tę hierarchię uświadomić, ponieważ od tego zależy jego prawo do wolności. Prawda o tej właściwej hierarchii pochodzącej wprost od Boga jest głoszona przez Kościół. Z tych powodów każdy człowiek powinien tak ukierunkować swój intelekt i wolę, aby mógł postępować zgodnie z tą hierarchią wartości. Oprócz prawd naturalnych poznawanych „zdrowym rozumem” powinien kierować się prawdami porządku boskiego (nadnaturalnego), przekraczającego zdolności poznawcze rozumu ludzkiego. $Z$ tego względu rozum ludzki uznając swą słabość, nie powinien sprzeciwiać się prawdom wyższego rzędu objawionym przez Boga i głoszonym przez Kościół katolicki. Oświecony wiarą rozum stanowi o wielkości człowieka. Te poglądy wyraźnie nawiązują do koncepcji św. Tomasza z Akwinu, o nich to bowiem, komentując Akwinatę, Etienne Gilson napisał: ,... wola jako natura jest

${ }^{81}$ Leon XIII ma tu zapewne na myśli, że nie mogą one być celem samym w sobie.

${ }^{82}$ Encyklika 'Libertas praestantissimus', [w:] Władza. Wolność, Prawo..., s. 188. Zdaniem B. Sutora, Etyka polityczna. Ujęcie całościowe na gruncie chrześcijańskiej nauki społecznej, Warszawa 1994, s. 229, Leon XIII uważał, że to co jest sprzeczne z prawdą i sprawiedliwością, może być przez państwo tolerowane tylko pod pewnymi warunkami, co najwyżej w imię wewnętrznego pokoju.

83 A. Rembowski, Encyklika o wolności ludzkiej, op. cit., s. 294. 
z konieczności zdeterminowana pragnieniem dobra ... wolność tkwi korzeniami w woli, chociaż jest również prawdą, że przyczyną wolności jest rozum. Wola dąży do dobra z konieczności, wynikającej z samej natury, z której wyrasta. Toteż swe niezdeterminowanie zawdzięcza wola tylko różnorodnym pojęciom dobra, podsuwanym jej przez rozum" ${ }^{\text {. }}$. Jak zauważył J. Keller, w odpowiedzi na zarzuty ze strony liberałów podnoszone przeciwko doktrynie katolickiej, że tłumi ona wolność, Leon XIII dowodził, że człowiek jest wolny, choć w swych decyzjach, swym myśleniu jest podporządkowany prawu boskiemu ${ }^{85}$.

Jak zaznaczyłem wcześniej, Leon XIII w znacznej mierze był kontynuatorem tradycyjnej katolickiej doktryny wolności religijnej i społecznej. W sposób przekonujący stara się to wytłumaczyć Bernhard Sutor twierdząc, iż „Odrzucenie indywidualnych praw człowieka (zapoczątkowanych przez Rewolucję Francuską - przyp. M. S.) przez Kościół w XIX w. poza względami historycznymi, opierało się na wyobrażeniu, że Kościół musi bronić obiektywnej prawdy zawartej w objawieniu i prawie natury przeciwko subiektywnej wolności czy nawet samowoli" ${ }^{\prime \prime 6}$.

Papież też nie uznawał zasady wolności religijnej rozumianej jako prawo przysługujące każdemu człowiekowi do wyboru tej czy innej religii. Nie uznawał również wolności głoszenia poglądów sprzecznych z „Boskim porządkiem” społecznym i państwowym. Zasady te zostały przyjęte przez Kościół katolicki dopiero kilkadziesiąt lat później podczas Soboru Watykańskiego II ${ }^{87}$.

${ }^{84}$ E. Gilson, Duch filozofii średniowiecznej, Warszawa 1960, s. 293.

85 J. KelLer, Katolicka doktryna społeczna, Warszawa 1989, s. 197.

${ }^{86}$ B. Sutor, op. cit., s. 228.

${ }^{87} \mathrm{~W}$ dokumentach Soboru Watykańskiego II czytamy: „Sobór Watykański oświadcza, iż osoba ludzka ma prawo do wolności religijnej. Tego zaś rodzaju wolność polega na tym, że wszyscy ludzie powinni być wolni od przymusu - tak aby w sprawach religijnych nikogo nie przymuszano do działania wbrew jego sumieniu", por. Dignitatis humanae. Deklaracja Soboru Watykańskiego II o wolności religijnej, (II) 1965 . 
Wobec powyższych wywodów należy stwierdzić że, za pontyfikatu Leona XIII katolicka koncepcja wolności religijnej nie uległa zmianie. Papież ten wprowadził jedynie pewne zmiany w stosunku do Grzegorza XVI i Piusa IX. Przemawiał innym językiem. Nie potępiał wszystkiego co nowe w poglądach na życie społeczne i polityczne. Próbował odróżnić to co jest możliwe do przyjęcia, od tego co należy odrzucić. W dużej mierze była to jednak zmiana sposobu wyrażania się o wolności niż faktyczny zwrot w nauczaniu Kościoła w tej kwestii ${ }^{8}$. Nie można zaprzeczyć, że w kwestii wolności Leon XIII nie był skłonny akceptować haseł liberałów. Nie uznał prawa człowieka do swobodnego wyboru wyznania, wolności prasy, czy wolności nauczania i głoszenia swoich przekonań. Uczyniono to kilkadziesiąt lat później /1965/, podczas Soboru Watykańskiego II.

Nauczanie Leona XIII w kwestii praw człowieka najpełniej zostało zaprezentowane w jego najbardziej znanej encyklice Rerum novarum, w której autor afirmował fundamentalne prawa robotników, ich ludzką godność i godność pracy ${ }^{89}$. W mojej ocenie w katalogu praw naturalnych przedstawionych przez papieża w tej enuncjacji najważniejsze było prawo człowieka do posiadania prywatnej własności, ponieważ w jego przekonaniu ,prawo do posiadania prywatnej własności otrzymał człowiek od natury" ${ }^{90}$. Zatem prawo to wynika z prawa natury i jak pouczał Leon XIII, choć Bóg oddał ziemię we władanie całemu rodzajowi ludzkiemu, to jednak nie zabronił człowiekowi posiadania prywatnej własności. Stwórca bowiem nie oddał ziemi ogółowi ludzi w tym znaczeniu, żeby wszyscy ludzie posiadali ją jako wspólną własność, lecz w ten sposób, iż sam żadnemu człowiekowi nie przeznaczając jakiejś wydzielonej części do posiadania, „pozostawił zapobiegliwości ludzkiej i urządzeniom ludów określenie granic i rozdzielenie

${ }^{88} \mathrm{~W}$ tym samym duchu por. też J. LeCLercQ, Katolicy $i$ wolność myśli, Kraków 1964, s. 133.

${ }^{89}$ Tak też E. STtIPHAN, Human rights: concepts and perspectives, New Delhi 2002, s. 25 .

${ }^{90}$ Rerum novarum, s. 4. Tak też odczytuje nauczanie papieskie Z. KĘDZıA, Burżuazyjna koncepcja praw człowieka, Wrocław-Warszawa-Kraków-Gdańsk 1980, s. 159, który stwierdził, że Leon XIII prawu do własności przypisał charakter naturalny. 
własności prywatnej”91. Nawet ziemia znajdująca się we władaniu poszczególnych ludzi, nie przestaje służyć ogółowi, bo wszyscy żyją z jej płodów. Z tego wynika, że ,istnienie własności osobistej nie sprzeciwia się wcale prawu natury" "92. Leon XIII wskazywał, że system własności prywatnej jest zgodny z naturą człowieka. Różnice zachodzące pomiędzy naturą człowieka i zwierzęcia wskazuja, że człowiek musi mieć prawo nie tylko do nabywania płodów ziemi, lecz także do posiadania samej ziemi. Ponieważ człowiek obdarzony jest rozumem, nie wystarczy mu, ,jak zwierzęciu, proste używanie dóbr doczesnych, lecz nadto potrzebne mu jest prawo własności stałej i trwałej" nie tylko do rzeczy zużywalnych, lecz także w stosunku do dóbr trwałych ${ }^{93}$. Skoro człowiek dzięki pracy nabywa prawo do posiadania określonej części dóbr ziemskich, jest zgodne z zasadą sprawiedliwości, aby ta część ziemi stała się jego własnością i aby nikomu nie było wolno naruszać tego prawa ${ }^{94}$. Ustawy państwowe, których celem jest dobro powszechne, powinny potwierdzać to prawo i chronić jego naruszenie przy pomocy odpowiednich sankcji ${ }^{95}$.

Z papieskiego uznania pracy za źródło własności wynikało, że prawo do własności powinno przysługiwać również robotnikom, bowiem tak jak skutek należy do przyczyny, tak owoce pracy powinny należeć do robotnika. Precyzując to stwierdzenie Stefan Wyszyński wyjaśnił, że odnosi się ono bezpośrednio do tych, którzy osobiście pracują we własnym warsztacie, na własnej ziemi, swoimi narzędziami i używając swoich materiałów, wtedy tylko człowiek ma prawo do całkowitego

91 Rerum novarum, s. 6.

92 Tamże.

93 Tamże, s. 5.

94 TAMŻE, S. 6, por. też: A. RAUSCHER, Własność prywatna w stużbie człowieka pracujacego, [w:] Chrześcijaństwo, demokracja, kapitalizm, M. NovAK, A. RAUSCHER, M. ZięBA, Poznań 1993, s. 71.

95 Tak też J. Keller, op. cit., s. 140, por. też szerzej na ten temat: J. Y. CALvez, J. Perrin, Kirche und Wirtschaft-Gesellschaft; Die Soziallehre der Päpste von Leo XIII. bis zu Johannes XXIII, II, Recklinghausen 1965, s. 36-44. 
wytworu swojej pracy ${ }^{96}$. Franciszek J. Mazurek skłonny jest twierdzić, że prawo do posiadania własności także przez robotników papież łączył z zasadą powszechnego przeznaczenia dóbr ${ }^{97}$. Leon XIII wywodził, że wynagrodzenie za pracę pozwoli im nabyć własność, ponieważ własność nabywana przez robotników najemnych jest rezultatem zaoszczędzonej płacy. „Przede wszystkim jasną jest rzeczą - nauczał papież - że zamiar, który kieruje robotnikiem przy podjęciu trudu nie jest inny, jeno ten, aby za pomocą zarobku dojść do jakiejkolwiek osobistej własności"98.

Papież pouczał, że robotnik ma prawo nie tylko do sprawiedliwej i słusznej płacy ${ }^{99}$, ale także do swobodnego dysponowania nią, to jest także do nabywania własności. Próba pozbawienia robotników tego prawa przez państwo byłaby zaprzeczeniem wolności dysponowania własną zapłatą. Człowiek nie otrzymuje tego prawa od państwa, bowiem człowiek jest „starszy” od państwa i ,posiadał prawo do zachowania swego życia cielesnego, zanim jeszcze istniało państwo ... (z czego wynika), że istnienie własności osobistej nie sprzeciwia się wcale prawu natury"100. Należy wskazać, że prawo własności w interpretacji papieskiej nie jest prawem absolutnym, nie podlegającym żadnym ograniczeniom, bowiem Leon XIII osadzał je w całokształcie katolickiej nauki o własności. Odwołując się do poglądów Akwinaty napisał w Rerum novarum: „Tej nauki podstawę stanowi rozróżnienie między sprawiedliwym posiadaniem majątku, a sprawiedliwym

96 S. WYsZYŃsKi, Socjalistyczna własność wspólna w ocenie 'Rerum novarum', «Ateneum Kapłańskie» 28/1931, s. 470.

${ }^{97}$ F. J. MAZUReK, op. cit., s. 35-36.

98 Rerum novarum, s. 3. „Jak skutek należy do przyczyny, która mu dała początek, tak samo owoc pracy sprawiedliwie przynależy temu, kto pracy dokonał", tamże, s. 7. Tak też A. Rauscher, op. cit., s. 97.

99 Tak też S. WyszyŃSKI, op. cit., s. 470, który stwierdził, że w systemie pracy fabrycznej, gdzie materiał i narzędzia pracy są własnością przedsiębiorcy, a tylko praca i jej wartość są wkładane przez robotnika, za którą jak za własność należy mu się słuszna zapłata.

${ }^{100}$ Rerum novarum, s. 5-6. 
majątku używaniem"101. Zastanawiając się nad problemem sposobu używania własności Leon XIII ponownie odpowiedział słowami św. Tomasza z Akwinu, „rzeczy zewnętrznych człowiek nie powinien za własne mieć, lecz za wspólne, tak iżby w potrzebie ludzkiej łatwo ich udzielał"102. Na właścicielu ciążą zatem pewne obowiązki społeczne. Po zaspokojeniu potrzeb swoich i swojej rodziny, stosownie do zajmowanego stanowiska $\mathrm{w}$ hierarchii społecznej powinien on wesprzeć ubogich. Zdaniem Leona XIII, „nie jest to obowiązek sprawiedliwości, lecz miłości, której w drodze prawnej wymuszać nie można" ${ }^{103}$. Wydaje się, że tę powinność papież pojmował jako chrześcijański obowiązek jałmużny ${ }^{104}$.

Obowiązki społeczne, które ciążą na właścicielu wiązać należy, z głoszoną przez papieża potrzebą działania na rzecz bonum commune. Stosunek Leona XIII do prawa własności, wypływa z jego przekonania, iż własność prywatna najlepiej zabezpieczy wolność i niezależność rodziny - tej „domowej społeczności”, która jest starsza od państwa, zatem jej prawa mają pierwszeństwo przed państwem ${ }^{105}$.

W przekonaniu papieża zniesienie własności prywatnej gwałci prawo naturalne, zakłóca powszechny pokój i podważa ustrój państwa, dlatego też „pierwszą podstawą, na której oprzeć należy dobrobyt ludu, jest nietykalność" własności prywatnej ${ }^{106}$. Dla Leona XIII

101 Tamże, s. 15, por. też, O. von Nell-Breuning, Soziallehre der Kirche, Wien 1977, s. 42-45.

102 Rerum novarum, s. 15.

${ }^{103}$ W Rerum novarum, s. 16, papież napisał: „Wszakże, gdzie uczyniono zadość potrzebie i przyzwoitości, tam obowiązek się zjawia obdarowania ubogich z tego, co pozostało". Por. też: W. OckENFELs, Kleine katholische Soziallehre: eine Einführung - nicht nur für Manager, Trier 1989, s. 30, szerzej na ten temat E. MuHLER, Die Soziallehre der Päpste, München 1958, s. 189-198.

104 Tak też nauczanie papieskie odczytał A. RAuscher, op. cit., s. 67.

105 Rerum novarum, s. 9, por. też, Cz. STrZeszewski, Katolicka nauka spoleczna, Lublin 1994, s. 251.

106 Tamże, s. 10. Wyrażone w encyklice poglądy skłoniły Cz. Strzeszewskiego, Własność. Zagadnienie społeczno-moralne, Warszawa 1981, s. 123, do stwierdzenia, że nauka społeczna Leona XIII znajdowała się pod wpływem XIX-wiecznego 
dobrobyt ludu, część bonum commune, opiera się na własności prywatnej ${ }^{107}$.

Obrona przez Leona XIII prawa człowieka do posiadania własności prywatnej wynikała z jego głębokiego przeświadczenia, iż własność prywatna jest kluczem do rozwiązania kwestii robotniczej.

Papież w encyklice Rerum novarum zajął się nie tylko prawem własności prywatnej, ale sformułował również szereg innych praw, do których zaliczył: prawo do decydowania o swoim życiu, prawo do wypoczynku, prawo do sprawiedliwej płacy, prawo do godziwych warunków pracy oraz prawo do zakładania stowarzyszeń i tworzenia związków zawodowych ${ }^{108}$.

Prawo człowieka do decydowania o wyborze stanu cywilnego Leon XIII uznał za prawo naturalne. Przejawem tego prawa jest małżeństwo. Papież napisał: ,żadna ustawa ludzka nie może odjaćc człowiekowi naturalnego i pierwotnego prawa do zawarcia małżeństwa"109. Wysnuć można z tego wniosek, że prawo do życia implikuje wprost prawo do zawarcia małżeństwa, bowiem poprzez zawarcie małżeństwa powstaje rodzina, ta „rzeczywista społeczność”, starsza od „każdego ustroju państwowego", która dzięki temu posiada prawa i obowiązki niezależnie od państwa. Leon XIII wyłożył pojęcie praw rodziny, a zwłaszcza prawo ojca rodziny. Wynikają one z tego, iż w państwie

liberalizmu. Strzeszewski wywodzi, że w Rerum novarum nie ma ścisłych sformułowań chrześcijańskich zasad społecznych i dlatego nadmiernie akcentowana jest rola prywatnej własności. W ocenie tego autora encyklikę z punktu widzenia doktrynalnego ratuje zgodność z tradycją chrześcijańską w kwestii rozumienia bonum commune. Wydaje się, że mocno odmienne stanowisko w analizowanej kwestii zaprezentował w swojej późniejszej pracy, Katolicka nauka społeczna..., s. 251-252, w której poglądy Leona XIII dotyczące własności prywatnej zostały ocenione pozytywnie.

107 Por. też: T. Rausch, Sexual morality and social justice, [w:] Contemporary Catholic Theology, ed.: M.A. Hayes, L. Gearon, New York 1999, s. 418. W ocenie tegoż autora własność prywatna służy dobru wspólnemu.

108 Tak też J. F. Mazurek, op. cit., s. 34. Pomijam tutaj te prawa człowieka, które wymieniłem w rozważaniach przedstawionych wcześniej, a dotyczących papieskiego rozumienia wolności, tj. wolności kultu, słowa i nauczania, w encyklice Libertas praestantissimum.

109 Rerum novarum, s. 7. 
podobnie jak w rodzinie, (która jest pierwotna wobec państwa) rządzi władza samodzielna, na wzór władzy ojcowskiej. Z tego względu „rodzina posiada co najmniej te same prawa, co państwo, w wyborze i zastosowaniu środków zabezpieczających jej byt i sprawiedliwąniezależność"110. Z tych wywodów wynika, że papież wyposażył rodziców a nie państwo - w prawo do decydowania o sposobie wychowania swoich dzieci. $Z$ tego powodu bowiem, iż dzieci, pod opieką pozostają rodzicielską zanim potrafią używać wolności woli, „władza ojcowska nie może być obaloną ani zagarniętą przez państwo"111. Tym samym zaprzeczał postulatom dotyczącym wychowania dzieci wysuwanym przez socjalistów.

Swoistym wyzwaniem jest precyzyjna delimitacja naturalnych i społecznych praw człowieka w nauczaniu Leona XIII, ponieważ niektóre z nich można by uznać zarówno za naturalne jak i społeczne prawa człowieka $^{112}$. W moim przekonaniu do praw społecznych należałoby zaliczyć te, które wynikają ze społecznej natury człowieka - członka organizmu społecznego. Bardzo często jednak prawa społeczne wiążą się z naturalnymi prawami człowieka, albo są ich konsekwencją. I tak np. prawo do wypoczynku, wymienione w Rerum novarum papież uzasadniał potrzebami duchowymi, a zwłaszcza religijnymi potrzebami człowieka ${ }^{113}$. Do takich praw stojących na pograniczu zaliczyłbym także: prawo do sprawiedliwej płacy, godziwych warunków pracy, prawo do zakładania stowarzyszeń, czy prawo człowieka do umiarkowanych podatków.

110 Tamże, s. 8. Rodzina, zdaniem Leona XIII, ma nawet pierwszeństwo przed państwem, bowiem ,pierwej istnieje od związku państwowego, za czem idzie, że mają pierwszeństwo i głębiej w naturze ugruntowane są jej prawa i powinności”.

111 Tamże, s. 9. Tak też P. Tischleder, op. cit., s. 85-88.

112 Por. też J. F. Mazurek, op. cit., 38. Autor ten zupełnie nie rozgranicza praw społecznych i naturalnych, dowodząc, że Leon XIII żądał od państwa ogłoszenia praw społecznych i skutecznej ich ochrony. Źródłem tych praw nie jest władza państwowa, ponieważ są to prawa naturalne, Tamże.

113 Rerum novarum, s. 15. 
Jak wiadomo w celu poprawy sytuacji robotników Leon XIII zalecał przeprowadzenie uwłaszczenia mas pracujących ${ }^{114}$, poprzez upowszechnienie własności ${ }^{115}$. W jego ocenie nie można tego osiągnąć poprzez likwidację własności prywatnej, czy nowy podział majątku społecznego i powstanie własności wspólnej, ale poprzez przyznanie robotnikom prawa do odpowiedniej płacy. Problem płacy powinien być, według Leona XIII rozwiązany przez pracodawców bardzo precyzyjnie: „pracować bowiem znaczy trudzić się w celu uzyskania środków służących ku zaspokojeniu potrzeb, a mianowicie ku zachowaniu życia" 116 .

Leon XIII uważał, iż praca posiada dwie nierozłącznie związane ze sobą cechy. Pierwszą z nich jest jej osobowy charakter ponieważ to osoba ludzka podejmuje się jej wykonywania i do tejże osoby z prawa natury należy praca jako „własność użytkowa”. Drugim, niezbywalnym atrybutem pracy jest jej konieczność, „ponieważ bez jej owoców nie obędzie się człowiek, jeśli chce życie zachować" ${ }^{117}$. $\mathrm{Z}$ tych powodów na pracodawcy ciąży obowiązek wypłacenia robotnikowi godziwej zapłaty. Taka płaca powinna robotnikowi „rządnemu i moralnemu" dostarczyć środków na utrzymanie siebie, żony i dzieci, a ponadto stworzyć możliwość odkładania oszczędności, ,aby z czasem dojść do skromnego majątku"118. Płaca, która powinna wystarczyć na utrzymanie robotnika i jego rodziny zyskała z czasem w katolickiej

114 Por. też Cz. Strzeszewski, Katolicka nauka społeczna, cit., s. 250.

115 Tak też K. Chojnicka, Nauczanie społeczne Kościoła, [w:] Doktryny polityczne XIX $i$ XX wieku, pod red. K. Chojnickiej, W. Kozuba-Ciembroniewicza, Kraków 2000, s. 273.

116 Rerum novarum, s. 29.

117 Tamże, s. 30.

118 Tamże, s. 31. Podobnie odczytuje nauczanie papieskie H. MAIER, Oświeceniowa idea wolności, a tradycja katolicka, [w:] Oświecenie dzisiaj. Rozmowy w Castel Gandolfo, Kraków 1999, s. 82, który nie zawahał się stwierdzić, że Leon XIII jako „papież społeczny” skorygował także współczesny mu liberalizm ekonomiczny, domagając się sprawiedliwych płac. 
nauce społecznej miano płacy „sprawiedliwej”, bądź „rodzinnej”119. Należy dobitnie podkreślić, że prawo człowieka do sprawiedliwej płacy zostało sformułowane w papieskiej nauce społecznej po raz pierwszy właśnie przez Leona XIII ${ }^{120}$. Na straży realizacji tego prawa stałoby państwo i robotnicze korporacje zawodowe.

W encyklice Rerum novarum Leon XIII sporo uwagi poświęcił celom i zasadom funkcjonowania chrześcijańskich stowarzyszeń robotniczych. Z ideą ich tworzenia wystapił już w encyklice Quod Apostolici muneris, w której pouczył o konieczności popierania związków zawodowych, których członkowie wspierając się, „stoją pod ochroną religii i żyją w pokoju" 121 .

Z powstaniem chrześcijańskich związków robotniczych papież wiązał nadzieje na rozwiązanie kwestii robotniczej przekonując, że korporacje te mogą odegrać równie ważną rolę jak państwo ${ }^{122}$. Zwłaszcza w kwestiach czasu pracy, środków ochrony zdrowia - pouczał papież - ,państwowa władza łatwo mogłaby postapić niestosownie, bezpieczniej zatem będzie odstapić te rzeczy do zbadania i załatwienia osobnym izbom czyli radom"123. W skład tych korporacji wchodziliby sami robotnicy, albo pracownicy wspólnie z pracodawcami.

Papież był przekonany, że obywatele mają niezależne od państwa prawo do stowarzyszenia się i dlatego muszą mieć swobodę w tworzeniu wewnętrznego prawa stowarzyszeńn ${ }^{124}$. Leon XIII zalecal, by poszczególne państwa poprzez własne ustawodawstwo zagwarantowały niezależność związków. Wszystkie wszak powinny służyć wspólne-

119 Kwestię sprawiedliwej, rodzinnej płacy podejmie w swoim nauczaniu również papież Pius IX. Por. też O. von Nell-Breuning, Einführung, [w:] Texte zur katholischen Soziallehre. Die sozialen Rundschreiben der Päpste und andere kirchliche Dokumente. Hrsg. Vom Bundesverband der Katholischen Arbeitnehmer-Bewegung /KAB/ Deutschlands, Kevelaer 1977, ss. 12-13.

120 Rerum novarum, s. 31. Por. też: F. KaMmer, Doing Faithjustice: An Introduction to Catholic Social Thought, New York 2004, s. 84.

${ }^{121}$ Quod Apostolici muneris, s. 65.

122 Por. J. Stolarczyк, Katolicyzm społeczny, Warszawa 1969, s. 75.

123 Rerum novarum, s. 31.

124 Tamże, s. 37. 
mu celowi ,iżby każdemu ze stowarzyszonych przybyło jak najwięcej dóbr, odnoszących się do ciała, duszy i majątku"125. Celem związków zawodowych jest polepszenie materialnego położenia robotników, a ponadto pomoc $\mathrm{w}$ uzyskaniu przez nich ich słusznych praw i zaspokojenie ich ekonomicznych żądań. Stowarzyszenia powinny troszczyć się, aby robotnik nie pozostawał bez pracy, tworzyć fundusz zapomogowy na wypadek choroby, bądź kryzysu gospodarczego, czy zabezpieczenia robotnika na starość ${ }^{126}$.

Nauczanie papieskie zakreśliło związkom zawodowym konkretne zadania w obronie słusznych interesów zrzeszonych robotników. Leon XIII wymieniał działania mające na celu stworzenie instytucji (papież nie nazwał ich) chroniących robotników przed bezrobociem, czy chorobą. W papieskiej ocenie pracownicze korporacje zawodowe, powinny być niezależne od państwa, albowiem prawo człowieka do swobodnego stowarzyszania się wypływa z prawa natury ${ }^{127}$.

Moim zdaniem to kategoria dignitas humana pozwoliła papieżowi sformułować pewne prawa pracownicze ${ }^{128}$, Leon XIII stwierdził bowiem, że przedsiębiorcy ze względu na ludzką godność robotnika nie mogą żądać od niego pracy w złych warunkach czy ponad jego siły, czy też nieodpowiedniej dla jego płci lub wieku ${ }^{129}$. Z kategorią ludz-

125 Tamże, s. 37-38, por. też: A. KudŁASZYK, Katolicka myśl społeczno-polityczna w Galicji na przełomie XIX i XX wieku, Wrocław 1980, s. 52.

${ }^{126} \mathrm{~W}$ encyklice papież napisał: „I tego również bardzo pilnować należy, iżby robotnikom nie brakło pracy i żeby istniał fundusz, z którego możnaby udzielać zapomóg członkom, $\mathrm{i}$ to nie tylko w czasie nieprzewidzianego przesilenia i zastoju w przemyśle, lecz także wtedy, gdy ich przyciśnie choroba, wiek sędziwy lub jakiekolwiek nieszczęście", Rerum novarum, s. 39.

127 Tak też H. MAIER, Oświeceniowa idea wolności..., 82, oraz K. CHOJNICKA, op.cit., s. 275.

${ }^{128}$ Szerzej w tej materii M. SADowsKI, Godność człowieka i dobro wspólne..., passim.

${ }^{129}$ Rerum novarum, s. 25, 28. Tak też: M.L. KRIER Mich, Catholic social teaching and movements, New York 1998, s. 43, a także R. Oswald, The Economy and workers ` jobs, the living wage and a voice, [w:] Catholic Social Teaching and the United States Economy: Working Papers for a Bishops'Pastoral, ed.: J.W. Houck, O. F. WiLliams, Washington D.C. 1984, s. 77. 
kiej godności wiązać należy również prawo robotników do wypoczyn$\mathrm{ku} \mathrm{w}$ dni świąteczne ${ }^{130}$.

Odmienne stanowisko wyraził ks. F.J. Mazurek, w którego ocenie Leon XIII, nauczając o prawach człowieka, nie odwoływał się bezpośrednio do kategorii dignitas humana. Godność osoby ludzkiej była dla niego fundamentalną normą moralną, oraz podstawą wolności i równości wszystkich ludzi ${ }^{131}$.

W niezmiernie interesujący sposób posłużył się papież ideą bonum commune do wezwania władz państwowych, aby te nakładały umiarkowane podatki na obywateli. W przekonaniu autora encykliki wspomniane w dokumencie korzyści, jakie odnieść może społeczeństwo, tylko wtedy dadzą się zrealizować, gdy prywatna własność nie będzie wyczerpywana przez nadmiar podatków i ciężarów publicznych. Władza państwowa bowiem nie może niszczyć prawa własności prywatnej (której źródłem jest, jak wiemy, nie wola ludzka, lecz natura), ale może tylko jego używanie ograniczać i do dobra ogółu dostosowywać. Tym samym każdy, kto by z prywatnej własności ściągał w postaci podatków więcej, niż się należy, działałaby niesprawiedliwie i niegodnie, ponieważ pomniejszałby dobro wspólne ${ }^{132}$.

$$
* * *
$$

Przedstawione powyżej poglądy Leona XIII na społeczne i naturalne prawa człowieka upoważniają do postawienia kilku wniosków końcowych.

Chociaż papieskie nauczanie było w znacznym stopniu skierowane przeciwko ideologii i ruchowi socjalistycznemu, to należy podkreślić, że zawiera ono w pełni oryginalne wątki, a jego rozwój następował niezależnie od koncepcji współczesnych mu myślicieli świeckich, pozostających poza Kościołem katolickim. Wzmiankowana oryginalność

130 Rerum novarum, s. 27. Por. też: Ch.E. Curran, The Moral Theology of Pope John Paul II, Washington D.C. 2005, s. 218.

131 Por. F. J. Mazurek, op. cit., s. 38.

132 Rerum novarum, s. 21. 
poglądów papieskich swój szczególny wyraz znalazła w leonowej idei praw człowieka ${ }^{133}$.

Zestawienie poglądów papieskich z liberalną doktryną praw człowieka wskazuje, że zarówno w nauczaniu papieskim, jak i w koncepcjach liberałów, nie tylko podmiot tych praw, ale niejednokrotnie ich przedmiot są tożsame. Bez wątpienia odmienne jest natomiast ich pochodzenie, dla liberałów bowiem źródłem praw człowieka będzie konwencja społeczna i prawo pozytywne. Z kolei dla Leona XIII fundamentem ludzkich praw jest przekonanie, że człowiek jako imago Dei posiada niezbywalną godność, stanowiącą fundament i źródło jego praw. Drugim źródłem praw człowieka w nauczaniu papieskim jest prawo naturalne, jak bowiem zauważył Johannes Messner ,prawo naturalne oznacza całość praw przynależnych człowiekowi na mocy jego natury"134.

Wielu komentatorów (W. Schwer, P. Tischleder) encykliki Rerum novarum wyraziło zgodny pogląd, że Leon XIII wśród ludzkich praw za najważniejsze uznał prawo człowieka do posiadania własności prywatnej ${ }^{135}$. Można nawet zauważyć, iż treść tej encykliki koncentruje się wokół tego prawa. Poszczególne prawa społeczne, które przedstawił papież, służą uzasadnieniu naturalnego, a zarazem i społecznego prawa człowieka do własności prywatnej. W pełni podzielam to stanowisko.

Głęboko uzasadniony wydaje się także pogląd głoszony przez Paul’a Bolte, który określił Rerum novarum jako pierwszą papie-

${ }^{133}$ R. TRAER, Faith in human rights: support in religious traditions for a global struggle, Washington D.C. 1991, s. 33, stwierdził, że chociaż korzenie katolickiego nauczania społecznego o prawach człowieka sięgają Biblii i Arystotelesa, to jednak jego współczesne rozumienie związane jest z pontyfikatem Leona XIII.

${ }^{134}$ Cyt. za F. Compagnoni, Prawa człowieka. Geneza, historia i zaangażowanie chrześcijańskie, Kraków 2000, s. 237.

135 Por. np. W. Schwer, Papst Leo XIII, Freiburg im Breisgau 1923, s. 41, oraz P. Tischleder, op. cit., s. 68. Autor ten w indeksie rzeczowym przy haśle „Eigentum” odsyła do hasła „Privateigentum”, s. 532. Inaczej widzi tę kwestię J.F. MAZUREK, op. cit., s. 35 . 
ską deklarację praw człowieka ${ }^{136}$. Z kolei J.F. Mazurek uważał, chyba nie do końca słusznie, że była to nie tyle deklaracja różnorodnych praw, ale „deklaracja praw społecznych"137. Natomiast René Coste, sulpicjanin z Wydziału teologii w Tuluzie, wytrawny znawca problematyki praw człowieka, interpretując postawę Kościoła wobec praw człowieka stwierdził, że łatwo daje się w niej początkowo zauważyć pewien dystans, który następnie stopniowo zanika, by w końcu zamienić Kościół w jednego z najbardziej aktywnych i przekonanych promotorów praw człowieka. Pierwsza głęboka przemiana w tej kwestii związana jest bowiem z Rerum novarum Leona XIII, gdzie mówi się o prawach robotników, dopiero zaś później Kościół zajął jasne stanowisko poprzez encykliki, przemówienia oraz wystąpienia papieży ${ }^{138}$. W mojej ocenie w pełni zasadny jest pogląd głoszący, że papieskie nauczanie o prawach człowieka istniało już przed tą najbardziej znaną encykliką następcy Piusa IX, jego genezy upatrywać należy bowiem już we wcześniejszych enuncjacjach autora Rerum novarum.

Należy zatem raz jeszcze podkreślić, że wypracowana przez Leona XIII koncepcja naturalnych i społecznych praw człowieka stanowiła przełom w nauczaniu społecznym Kościoła katolickiego, a ponadto została zaprezentowana po raz pierwszy przez tego właśnie papieża. Papież Leon XIII w swoim nauczaniu długo przed ogłoszeniem przez ONZ (1948) Powszechnej Deklaracji Praw Człowieka, uznał godność osoby ludzkiej i prawa człowieka za fundamenty porządku społecznopolitycznego ${ }^{139}$.

136 P. E. Bolte, Les droits de l'homme et la papauté contemporaine, Montreal 1975, s. 20 .

137 J. F. MazureK, op. cit., s. 34. J. Bryan Hehir, Religious activism for human rights: a Christian case study, [w:] Religious human rights in global perspective: religious perspectives, ed.: J. Witte, J. D. VAn der Vyver, The Hague-Boston- London 1996, s. 101 używa określenie „ekonomiczne prawa człowieka.

138 Por. R. Coste, L'Eglise et droits de l'homme, Paris-Tournai 1983, s. 19.

139 Tak też J. Messner, Die Magna Charta der Sozialordnung. 90. Jahre Rerum novrum, «Kirche und Gesellschaft» 76/1981, s. 7. 


\section{The Natural and Social Human Rights in the Pope Leon XIII's Teaching}

\section{Summary}

The aim of this paper is to show that the category of human rights, one of the fundamentals of the modern political debate, was present in the pope's social teaching since its beginning, namely since the pontificate of Leon XIII (1878 - 1903).

A comparison between the pope's views and the liberal doctrine of human rights indicates that both in the pope's teaching and in the liberal conceptions, not only the subject of those rights but also their object are repeatedly identical. Their origin though is undoubtedly different. For the liberals the source of human rights are the social convention and the positive law. For Leon XIII the fundamental of human rights is the conviction that human being as imago Dei possesses an inalienable dignity which constitutes the foundation and the source of his rights. The second source of human rights in the pope's teaching is the natural law.

Leon XIII considered the right to possess private property to be the most important of human rights. The conception of natural and social human rights developed by him was a turning point in the social teaching of the Catholic Church, and moreover it was Leon XIII who presented it for the first time. 